\title{
Wzięcie udziału przez prokuratora w postępowaniu cywilnym jako gwarancja zapewnienia efektywności ochrony prawnej'
}

\section{Uwagi wprowadzające}

\begin{abstract}
A naliza przepisów ustawy z dnia 28 stycznia 2016 r. - Prawo o prokuraturze ${ }^{2}$ Aoraz rozporządzenia Ministra Sprawiedliwości z dnia 7 kwietnia 2016 r. Regulaminu wewnętrznego urzędowania powszechnych jednostek organizacyjnych prokuratury ${ }^{3}$ nie pozostawia cienia wątpliwości, że Prokuratura wykonuje zadania $\mathrm{w}$ zakresie ścigania przestępstw oraz stoi na straży praworządności (art. 2 Prawa o prokuraturze). O ile przeważająca część aktywności Prokuratora Generalnego, Prokuratora Krajowego i pozostałych zastępców Prokuratora Generalnego oraz podległych im prokuratorów obejmuje prowadzenie lub nadzorowanie postępowania przygotowawczego w sprawach karnych oraz sprawowanie funkcji oskarżyciela publicznego przed sądami, jak również koordynowanie działalności w zakresie ścigania przestępstw lub przestępstw skarbowych, prowadzonej przez inne organy państwowe, współdziałanie z organami państwowymi,
\end{abstract}

\footnotetext{
* Dr hab. Joanna Misztal-Konecka, prof. KUL - Katedra Postępowania Cywilnego KUL, Sędzia Sądu Okręgowego w Lublinie; e-mail: joannamisztal@kul.pl.

1 Artykuł stanowi pełne przedstawienie tytułowego zagadnienia w oparciu o analizę obowiązujących przepisów prawa polskiego i orzecznictwa, w nawiązaniu do rozwiązań i gwarancji europejskich. Główne tezy, rozwinięte w niniejszym opracowaniu, zostały juz zasygnalizowane w artykule The participation of the prosecutor in civil proceedings as a guarantee of ensuring the effectiveness of legal protection. Some remarks złożonym do publikacji w Review of Comparative Law.

${ }^{2}$ Dz.U. poz. 177 ze zm.

${ }^{3}$ Dz.U. poz. 508 ze zm.
} 
państwowymi jednostkami organizacyjnymi i organizacjami społecznymi w zapobieganiu przestępczości i innym naruszeniom prawa, o tyle nie można nie dostrzegać, że do zadań Prokuratury należy także wytaczanie powództw w sprawach cywilnych oraz składanie wniosków i udział w postępowaniu sądowym w sprawach cywilnych, z zakresu prawa pracy i ubezpieczeń społecznych, jeżeli tego wymaga ochrona praworządności, interesu społecznego, własności lub praw obywateli. Dodatkowo zakres kompetencji prokuratora w tych sprawach obejmuje podejmowanie środków przewidzianych prawem, zmierzających do prawidłowego i jednolitego stosowania prawa w postępowaniu sądowym.

Ustawodawca zwykły dostrzega zatem możliwość odegrania przez prokuraturę istotnej roli również na gruncie szeroko pojętego postępowania w sprawach cywilnych. Przepisy Prawa o prokuraturze w zakresie realizacji obowiązków prokuratora w postępowaniu cywilnym odsyłają do regulacji ustaw szczególnych (art. 67 Prawa o prokuraturze) i regulaminu (art. $36 \$ 1$ pkt 8 Prawa o prokuraturze). Ten ostatni akt prawny, co należy podkreślić z punktu widzenia dalszych rozważań - o charakterze podustawowym - w $\$ 353-365$ a wskazuje na sposób realizacji zadań związanych $\mathrm{z}$ udziałem prokuratora $\mathrm{w}$ sprawach cywilnych, rodzinnych, opiekuńczych oraz ze stosunku pracy i z zakresu ubezpieczeń społecznych.

Na gruncie ustawy cywilnej procesowej kluczowe znaczenie dla określenia zakresu działania prokuratora ma norma art. 7 zd. 1 K.p.c. ${ }^{4}$, zgodnie z którą prokurator może żądać wszczęcia postępowania w każdej sprawie, jak również wziąć udział w każdym toczącym się już postępowaniu, jeżeli według jego oceny wymaga tego ochrona praworządności, praw obywateli lub interesu społecznego ${ }^{5}$. $\mathrm{Z}$ dwóch formuł aktywności prokuratura w postępowaniu

${ }^{4}$ Udział prokuratora w niektórych rodzajach spraw cywilnych przewidują też przepisy szczególne, wśród których warto wymienić m.in. art. 26 ust. 3 ustawy z 26 października 1982 r. o wychowaniu w trzeźwości i przeciwdziałaniu alkoholizmowi (t.j. Dz.U. z 2016 r., poz. 487 ze zm.); art. 46 ust. 4 ustawy z 19 sierpnia 1994 r. o ochronie zdrowia psychicznego (t.j. Dz.U. z 2016 r., poz. 546 ze zm.); art. 36, 39 i 40 ustawy z 28 listopada 2014 r. - Prawo o aktach stanu cywilnego (t.j. Dz.U. z 2016 r., poz. 2064 ze zm.).

${ }^{5}$ Tematyce udziału prokuratora w postępowaniu cywilnym poświęcono dotychczas kilka monografii (zob. zwłaszcza K. Stefko, Udział prokuratora w postępowaniu cywilnym, Warszawa 1956; A. Meszorer, Stanowisko i czynności procesowe prokuratora w postępowaniu cywilnym, Warszawa 1957; W. Masewicz, Prokurator w postępowaniu cywilnym, Warszawa 1975; P. Wiśniewski, Udział prokuratora w postępowaniu cywilnym, Torun 2014; M. Kosek, Powództwo prokuratora w sprawach niemajątkowych z zakresu prawa rodzinnego, Warszawa 2016), jak też szereg artykułów omawiających często zagadnienia szczegółowe (zob. np. E. Wengerek, Udział prokuratora w postępowaniu cywilnym w świetle polskiej literatury prawniczej, Studia Cywilistyczne 1963, t. 3, s. 163-214; W. Broniewicz, Powództwo prokuratora w polskim procesie cywilnym, Państwo i Prawo 1966, z. 7-8, s. 31-43; S. Włodyka, Udział prokuratora w postępowaniu cywilnym w świetle nowego ustawodawstwa, Nowe Prawo 1966, nr 9, s. 1044-1053; K. Lubiński, Udział prokuratora w postępowaniu nieprocesowym w ujęciu prawno-porównawczym, w: Proces i prawo. Rozprawy prawnicze. Księga pamiątkowa 
cywilnym ${ }^{6}$ przedmiotem analizy w niniejszym artykule będzie wyłącznie zagadnienie wzięcia udziału przez prokuratora w toczącym się postępowaniu w kontekście efektywności ochrony sądowej oraz zasady równouprawnienia stron, zgodnie zktórą przepisy prawa procesowego normujące prawa i obowiązki stron mają w sposób jednakowy, zapewniający sprawiedliwe i równe warunki prowadzenia sporu, gwarantować obu stronom rzeczywistą i jednakową możliwość uzyskania ochrony prawnej.

Efektywność postępowania należy do podstawowych założeń postępowania sądowego i stanowi konieczny warunek rzetelnego procesu. Zapewnienie efektywności postępowania wymaga pogodzenia podstawowego celu procesu, jakim jest wydanie sprawiedliwego orzeczenia (tak z punktu widzenia norm prawa materialnego, jak i poszanowania gwarancji procesowych stron), z postulatem rozpatrzenia sprawy bez nieuzasadnionej zwłoki ${ }^{7}$. Efektywna ochrona prawna

ku czci Profesora Jerzego Jodłowskiego, red. E. Łętowska, Wrocław-Warszawa 1989, s. 139-155; W. Broniewicz, Prokurator w cywilnym postępowaniu kasacyjnym, Prokuratura i Prawo 1997, nr 9, s. 14-19; P. Wiśniewski, Udział prokuratora w postępowaniu cywilnym. Część I, Prokuratura i Prawo 1997, nr 10, s. 62-73; Część II, Prokuratura i Prawo 1997, nr 11, s. 57-78; M. Kozaczek, Prokurator w postępowaniu upadłościowym, Prokuratura i Prawo 2005, nr 5, s. 82-94; T. Zembrzuski, Rola Prokuratora Generalnego w cywilnym postępowaniu kasacyjnym, Prokuratura i Prawo 2006, nr 2 s. 151-162; B. Deskiewicz, Udział prokuratora w postępowaniu o zaprzeczenie pochodzenia dziecka poczętego w drodze sztucznej inseminacji heterologicznej, Prokuratura i Prawo 2007, nr 9, s. 107-117; Z. Zawadzka, Formy udziału prokuratora w postępowaniu cywilnym, Prokuratura i Prawo 2009, nr 10, s. 85-103; Z. Zawadzka, Pozycja procesowa prokuratora w postępowaniu cywilnym, Prokuratura i Prawo 2010, nr 6. s. 126-136; A. Jaworski, Legitymacja prokuratora do złożenia wniosku o zmiane postanowienia w przedmiocie obowiązku poddania sięleczeniu odwykowemu. Glosa do postanowienia $z$ dnia 9 października 2009 r. (IV CSK 210/09), Przegląd Sądowy 2011, nr 5, s. 116-121; A. Jaworski, Udział prokuratora w postępowaniu cywilnym przed Sądem Najwyższym, Polski Proces Cywilny 2011, nr 3, s. 87-117; A. Franusz, Dokonywanie czynności dyspozytywnych o charakterze materialnym w procesie z powództwa prokuratora na rzecz oznaczonej osoby, Prokuratura i Prawo 2016, nr 9, s. 109-130).

${ }^{6}$ Dodatkowo w literaturze wskazuje się na trzeci, szczególny sposób udziału - tylko Prokuratora Generalnego w postępowaniu cywilnym - przedstawienie przez niego stanowiska co do skargi kasacyjnej i skargi o stwierdzenie niezgodności z prawem prawomocnego orzeczenia oraz odpowiedzi na nie (art. 3988 i 42412). Zob. M. Sychowicz, w: Kodeks postępowania cywilnego. Tom I. Komentarz. Art. 1-366, red. A. Marciniak, K. Piasecki, wyd. 7, Warszawa 2016, s. 92; J. Bodio, w: Kodeks postępowania cywilnego. Tom I. Komentarz do art. 1-729, red. A. Jakubecki, wyd. 7, Warszawa 2017, s. 48.

7 Prawo do sądu, którego elementem jest również prawo do właściwego ukształtowania procedury, gwarantowane jest normami konstytucyjnymi (art. 45 ust. 1 Konstytucji Rzeczypospolitej Polskiej z dnia 2 kwietnia 1997 r., Dz.U. Nr 78, poz. 483 ze zm.), umów międzynarodowych (art. 6 Konwencji o ochronie praw człowieka i podstawowych wolności, sporządzonej w dniu 4 listopada 1950 r. w Rzymie, Dz.U. z 1993 r. Nr 61, poz. 284 ze zm.) oraz ustaw zwykłych (np. art. 3 K.p.c., art. 6 $\$ 1$ K.p.c.). Na temat efektywności postępowania cywilnego zob. też E. Wengerek, Zakres sq̨dowej ochrony w sprawach cywilnych, Państwo i Prawo 1975, z. 3, s. 44-58; W. Resich, Efektywność postępowania cywilnego w: Proces i prawo. Rozprawy prawnicze. Ksiega pamiątkowa ku czci Profesora Jerzego Jodłowskiego, red. E. Łętowska, Wrocław-Warszawa 1989, s. 463-471 (wprawdzie Autor ten odnosił się do również do poszanowania zasady prawdy obiektywnej jako elementu efektywności postępowania, co w obecnym kształcie Kodeksu postępowania cywilnego nie znajduje podstawy, jednakże aktualne pozostają uwagi co do szybkości postępowania, realności udzielanej ochrony 
musi być przy tym ochroną rzeczywistą i konkretną, a nie pozorną i abstrakcyjną ${ }^{8}$, tylko bowiem rzeczywiste a nie pozorne prawo do sądu stanowi realizację fundamentalnej zasady państwa prawnego ${ }^{9}$.

Warto zatem zastanowić się na ile obecnie obowiązujące regulacje prawa polskiego realizują - właśnie poprzez udział prokuratora - postulat efektywnej ochrony sądowej.

\section{Ustawowe przesłanki udziału prokuratora w postępowaniu cywilnym}

Art. 7 K.p.c. określa jakie przesłanki uzasadniają wzięcie udziału przez prokuratora w postępowaniu cywilnym. Wymienia on potrzebę ochrony:

- praworządności,

- praw obywateli,

- interesu społecznego ${ }^{10}$.

Ochrona praworządności rozumiana jest jako całokształt stosunków społecznych uregulowanych przez prawo ${ }^{11}$, zasad wykształconych w panującym

prawnej, praworządności jako jej składowych); T. Ereciński, K. Weitz, Efektywność ochrony prawnej udzielanej przez sady w Polsce, Przegląd Sądowy 2005, nr 10, s. 3-30.

${ }^{8}$ P. Pogonowski, Realizacja prawa do sadu w postępowaniu cywilnym, Warszawa 2005, s. 8; K. Flaga-Gieruszyńska, Dostęp do sądu a postulat humanizacji postępowania cywilnego, w: Aurea praxis. Aurea theoria. Księga pamiątkowa ku czci Profesora Tadeusza Erecińskiego, red. J. Gudowski, K. Weitz, t. 2, Warszawa 2011, s. 2787.

${ }^{9}$ Uchwała Trybunału Konstytucyjnego z dnia 25 stycznia 1995 r., W 14/94, OTK 1995/1/19.

${ }^{10} \mathrm{~W}$ obowiązującym rozporządzeniu Ministra Sprawiedliwości z dnia 7 kwietnia 2016 r. - Regulamin wewnętrznego urzędowania powszechnych jednostek organizacyjnych prokuratury wskazano następujące sprawy, w których zgłoszenie udziału prokuratora w postępowaniu sądowym jest wskazane: 1) których okoliczności wskazują na to, że postępowanie dotyczy oświadczenia woli złożonego dla pozoru lub dla ukrycia innej czynności prawnej albo że strony mają na celu obejście ustawy; 2) przeciwko Skarbowi Państwa, jednostce samorządu terytorialnego lub innej właściwej osobie prawnej o naprawienie szkody wyrządzonej przy wykonywaniu władzy publicznej; 3) o stwierdzenie nieważności czynności prawnej skutkującej przeniesieniem własności lub obciążeniem nieruchomości; 4) dotyczących ochrony dóbr kultury oraz ochrony praw autorskich lub praw pokrewnych; 5) o zwolnienie od egzekucji przedmiotów majątkowych zajętych w postępowaniu karnym lub postępowaniu o przestępstwo skarbowe, chyba że prokurator jest jednym z pozwanych; 6) dotyczących ochrony rodziny, w tym toczących się w trybie Konwencji dotyczącej cywilnych aspektów uprowadzenia dziecka za granicę sporządzonej w Hadze dnia 25 października 1980 r.; 7) o naprawienie szkody na osobie lub mieniu wyrządzonej szczególnie drastycznym działaniem sprawcy; 8) dotyczących ochrony środowiska naturalnego ( $\$ 360$ ust. 1). Równocześnie $\mathrm{w} \$ 364-365$ wskazano precyzyjnie sprawy z zakresu prawa rodzinnego i opiekuńczego oraz ze stosunku pracy i z zakresu ubezpieczeń społecznych, w których udział prokuratora w postępowaniu jest wskazany. Zob. też L. Mazowiecka, Prokuratura $w$ Polsce 1918-2014, Warszawa 2015, s. 203-210.

${ }^{11}$ B. Bladowski, Metodyka pracy sędziego cywilisty, wyd. 3, Warszawa 2009, s. 137. Szerzej na temat pojęcia praworządności zob. np. A. Bień-Kacała, Zasada praworządności i jej gwarancje w Konstytucji 
systemie prawnym, przy czym słuszne uznaje się, że jest to w istocie przesłanka nadrzędna ${ }^{12}$. Przez praworządność rozumieć należy bowiem „stan (sytuację), w którym całokształt danych stosunków jest uregulowany przez prawo w sposób jasny i z poszanowaniem hierarchii norm prawnych, przy czym prawo to, dla wszystkich równe i zapewniające minimum praw i swobód obywatelskich, jest przestrzegane przez wszystkich"13.

Ochrona praw obywateli staje się aktualnym celem prokuratora, gdy jednostki, w praktyce $\mathrm{z}$ powodu szczególnych przeszkód, nie są $\mathrm{w}$ stanie chronić swoich praw same, np. z powodu nieporadności, lub też zachodzi konieczność rozstrzygnięcia zagadnienia prawnego budzącego szczególne wątpliwości lub mającego precedensowe znaczenie ${ }^{14}$. Pojęcie ochrony praw obywateli obejmuje nie tylko osoby fizyczne (w tym cudzoziemców), ale także osoby prawne i jednostki organizacyjne ${ }^{15}$, jest to $\mathrm{w}$ istocie przesłanka naruszenia praw podmiotowych ${ }^{16}$.

Wreszcie wymieniona w art. 7 K.p.c. ochrona interesu społecznego to ochrona dobra wspólnego (interesu ogólnego) ${ }^{17}$, znajdująca swoje aksjologiczne uzasadnienie w art. 1 i 2 Konstytucji, które statuują, iż Rzeczpospolita Polska jest dobrem wspólnym wszystkich oraz demokratycznym państwem prawnym, urzeczywistniającym zasady sprawiedliwości społecznej. Jak słusznie wskazano w literaturze, chodzi tu w szczególności o działanie na rzecz ochrony i dalszego rozwoju instytucji demokratycznego państwa prawa, istniejących w nim stosunków własnościowych oraz systemu gospodarczego i zasad jego funkcjonowania, a także o ochronę rodziny, małżeństwa i małoletnich dzieci ${ }^{18}$.

Powszechnie uznaje się, że decyzję o wszczęciu postępowania bądź o wstąpieniu do niego prokurator podejmuje samodzielnie i nie podlega ona kontroli sądu ${ }^{19}$, a zwłaszcza brak podstaw do uznania, że sąd władny jest oddalić powództwo

$R P$ z 1997 r., w: Praworządność i jej gwarancje, red. D. Kala, Warszawa 2009, s. 45-60 wraz z literaturą tam przywołaną.

${ }_{12}$ M. Jędrzejewska (aktualizacja P. Grzegorczyk), w: Kodeks postępowania cywilnego. Komentarz. Tom I. Postępowanie rozpoznawcze, red. T. Ereciński, wyd. 5, Warszawa 2016, s. 188.

${ }_{13}$ Z. Resich, Nauka o organach ochrony prawnej, Warszawa 1973, s. 19. Tak też np. P. Wiśniewski, Udział prokuratora w postępowaniu cywilnym, Toruń 2014, s. 55; K. Gajda-Roszczynialska, w: Kodeks postępowania cywilnego. Komentarz. Tom I. Art. 1-729, red. A. Góra-Błaszczykowska, wyd. 2, Warszawa 2016, s. 78; M. Sychowicz, op.cit., s. 93.

${ }^{14}$ M. Sychowicz, op.cit., s. 93.

${ }_{15}$ Z. Resich, w: Kodeks postępowania cywilnego. Komentarz, red. Z. Resich, W. Siedlecki, t. 1, wyd. 2, Warszawa 1975, s. 76; B. Bladowski, op.cit., s. 137; M. Sychowicz, op.cit., s. 94. Odmiennie por. W. Masewicz, Prokurator ..., s. 38.

${ }^{16}$ M. Jędrzejewska (aktualizacja P. Grzegorczyk), op.cit., s. 190.

17 P. Wiśniewski, Udział prokuratora w postępowaniu cywilnym, Toruń 2014, s. 55; K. Gajda-Roszczynialska, w: Kodeks ..., s.78.

${ }_{18}$ W. Masewicz, Prokurator ..., s. 39; M. Sychowicz, op.cit., s. 94.

19 Z. Resich, w: Kodeks ..., s. 76; K. Lubiński, op.cit., s. 148; B. Bladowski, op.cit., s. 137; M. Jędrzejewska (aktualizacja P. Grzegorczyk), op.cit., s. 190, 379; K. Gajda-Roszczynialska, w: Kodeks ..., s. 79; 
(wniosek) wniesione przez prokuratora z powołaniem się na brak przesłanek, o których mowa w art. 7 K.p.c. Pozycja prokuratora w sporze opiera się bowiem na jego własnej legitymacji (czynnej), zwanej w literaturze legitymacją publicznoprawną ${ }^{20}$.

Stosownie do art. 60 K.p.c. prokurator może wstąpić do postępowania w każdym jego stadium ${ }^{21}$ : przed sądem pierwszej instancji, przed sądem drugiej instancji, a nawet przed Sądem Najwyższym; może w szczególności wstąpić do sprawy, składając równocześnie wniosek o sporządzenie uzasadnienia orzeczenia i jego doręczenie wraz z uzasadnieniem ${ }^{22}$; może wstąpić do postępowania wywołanego wniesieniem skargi o stwierdzenie niezgodności z prawem prawomocnego orze-

M. Sychowicz, op.cit., s. 94, 270-272; J. Bodio, w: Kodeks ..., s. 50; P. Telenga, w: Kodeks postępowania cywilnego. Tom I. Komentarz do art. 1-729, red. A. Jakubecki, wyd. 7, Warszawa 2017, s. 109.

20 Tak też postanowienie Sądu Najwyższego z dnia 5 grudnia 1979 r., II CZ 121/79, OSNC 1980/6/124; wyrok Sądu Najwyższego z dnia 9 marca 1993 r., I CR 3/93, OSNC 1993/9/165; wyrok Sądu Najwyższego z dnia 3 lutego 1999 r., III CKN 167/98, LEX nr 483310; wyrok Sądu Najwyższego z dnia 2 sierpnia 2007 r., V CSK 109/07, OSNC 2008/9/107; wyrok Sądu Apelacyjnego we Wrocławiu z dnia 1 marca 2012 r., I ACa 111/12, LEX nr 1130913; wyrok Sądu Apelacyjnego w Lublinie z dnia 10 grudnia 2013 r., I ACa 587/13, LEX nr 1416187; postanowienie Sądu Najwyższego z dnia 3 grudnia 2014 r., IV CSK 365/14, LEX nr 1566730; wyrok Sądu Apelacyjnego w Krakowie z dnia 12 stycznia 2016 r., I ACa 1332/15, LEX nr 2004520; wyrok Sądu Apelacyjnego w Łodzi z dnia 18 lutego 2016 r., I ACa 775/15, LEX nr 2005581. Zob. też orzeczenie Sądu Najwyższego z dnia 28 stycznia 1949 r., C 1089/48, LEX nr 310177. Zob. nadto J. Bodio, Interes prawny a interes publiczny prokuratora wytaczajacego powództwo w trybie art. 7,57 i 189 k.p.c., Palestra 2015, nr 1-2, s. 50-51; K. Gajda-Roszczynialska, w: Kodeks ..., s. 75.

${ }^{21}$ Dodatkowo udziału prokuratora dotyczą następujące regulacje szczególne:

- w sprawach o ubezwłasnowolnienie udział prokuratora jest obowiązkowy (art. $546 \$ 2$ K.p.c.);

- w sprawach o unieważnienie albo o ustalenie istnienia lub nieistnienia małżeństwa, a także w sprawach o zaprzeczenie pochodzenia dziecka lub o ustalenie bezskuteczności uznania ojcostwa, albo o rozwiązanie przysposobienia odpis pozwu doręcza się prokuratorowi i zawiadamia się go o terminach rozprawy (art. $449 \$ 1$ K.p.c.; art. 457 K.p.c.),

- o toczącym się postępowaniu w sprawach, w których wniosek o przysposobienie dotyczy dziecka niezgłoszonego do ośrodka adopcyjnego, sąd opiekuńczy zawiadamia prokuratora (art. 5852 K.p.c.),

- w sprawach o odebranie osoby podlegającej władzy rodzicielskiej lub pozostającej pod opieką prokuratorowi doręcza się odpis wniosku i zawiadamia się go o terminach rozprawy (art. $5981 \S 1$ K.p.c.).

Poza sprawami o ubezwłasnowolnienie udział prokuratora w postępowaniu nie jest obowiązkowy, choćby przepisy nakazywały doręczać mu pisma procesowe i zawiadomienia o terminie rozprawy. Zob. też J. Jodłowski, Glosa do wyroku [Sądu Najwyższego] z 10 II 1972, II CR 663/71, Państwo i Prawo 1973, z. 4, s. 162-166; M. Sychowicz, op.cit., s. 94; M. Jędrzejewska (aktualizacja P. Grzegorczyk), op.cit., s. 379; K. Gajda-Roszczynialska, w: Kodeks ..., s. 86. Zob. też postanowienie Sądu Najwyższego z dnia 14 grudnia 1965 r., I CR 337/65, OSNC 1966/7-8/131; uchwała Sądu Najwyższego z dnia 24 czerwca 1966 r., III CZP 42/66, OSNC 1966/12/210; postanowienie Sądu Najwyższego z dnia 4 marca 1969 r., II CR 20/69, OSNPG 1969/6/44.

Odmiennie jednak por. postanowienie Sądu Najwyższego z dnia 20 stycznia 1967 r., I CZ 149/66, OSNC 1967/9/158.

${ }^{22}$ Gdy prokurator, który nie bierze udziału w sprawie, złoży wniosek o doręczenie orzeczenia $\mathrm{z}$ uzasadnieniem, to termin do zaskarżenia liczy się od daty doręczenia mu orzeczenia z uzasadnieniem. Taki skutek następuje wtedy, gdy prokurator złożenie wniosku o doręczenie orzeczenia z uzasadnieniem połączy ze wstąpieniem do postępowania na podstawie art. $60 \$ 1$ K.p.c. (postanowienie Sądu Najwyższego z dnia 2 października 2003 r., V CZ 88/03, LEX nr 84308). 
czenia, postępowania prowadzonego na skutek skargi o wznowienie postępowania, a także w postępowaniu przed Sądem Najwyższym prowadzonym na skutek zagadnienia prawnego przedstawionego do rozstrzygnięcia w konkretnej sprawie (art. 390 i $398^{17}$ K.p.c., art. 59 ustawy o Sądzie Najwyższym) lub na skutek wniosku o rozstrzygnięcie wątpliwości, które ujawniły się w orzecznictwie sądów powszechnych, sądów wojskowych lub Sądu Najwyższego (art. 60 ustawy o Sądzie Najwyższym).

W orzecznictwie Sądu Najwyższego utrwalone jest stanowisko, że oświadczenie prokuratora o wstąpieniu do sprawy musi być wyraźne, zaś samo uprzednie zawiadomienie prokuratora o toczącym się postępowaniu (doręczenie mu odpisu pozwu czy też zawiadomień o terminie rozprawy) nie czyni go uczestnikiem tego postępowania ${ }^{23}$. Pojawienie się prokuratora w toczącym się postępowaniu nie oznacza, że zajmuje on stanowisko powoda ${ }^{24}$ lub pozwanego; prokurator też nie sanuje braku legitymacji wnioskodawcy w postępowaniu nieprocesowym ${ }^{25}$. Co więcej, prokurator może przestać brać udział w sprawie, do której wstąpił. Wymaga to jednak wyraźnego, przeznaczonego dla sądu oświadczenia prokuratora, że uznał już swoją rolę za zbędną i wobec tego nie będzie brać dalszego udziału w sprawie ${ }^{26}$.

\section{Znaczenie zawiadomienia prokuratora przez sąd o potrzebie jego udziału w postępowaniu cywilnym}

Istotnym zagadnieniem, które chciałabym uczynić przedmiotem analizy, jest relacja norm art. 7 i art. 59 K.p.c. Stosownie do pierwszej z nich wzięcie udziału przez prokuratora w postępowaniu cywilnym warunkowane jest tym, by wedle jego oceny wymagała tego ochrona praworządności, praw obywateli lub interesu społecznego. Natomiast art. 59 K.p.c. określa, że sąd zawiadamia prokuratora o każdej sprawie, w której udział jego uważa za potrzebny.

Sąd prowadzący postępowanie cywilne ${ }^{27}$ powinien zatem powiadomićc ${ }^{28}$ prokuratora, jeżeli uznaje, że przesłanki wskazane w art. 7 K.p.c. przemawiają

23 Postanowienie Sądu Najwyższego z dnia 14 grudnia 1965 r., I CR 337/65, OSNC 1966/7-8/131; uchwała Sądu Najwyższego z dnia 24 czerwca 1966 r., III CZP 42/66, OSNC 1966/12/210; postanowienie Sądu Najwyższego z dnia 23 grudnia 1968 r., I PZ 67/68, LEX nr 6434; postanowienie Sądu Najwyższego z dnia 4 marca 1969 r., II CR 20/69, OSNPG 1969/6/44; postanowienie Sądu Najwyższego z dnia 2 października 2003 r., V CZ 88/03, LEX nr 84308. Zob. też M. Sychowicz, op.cit., s. 97; M. Jędrzejewska (aktualizacja P. Grzegorczyk), op.cit., s. 379.

24 Wyrok Sądu Najwyższego z dnia 10 lutego 1972 r., II CR 663/71, OSNC 1972/7-8/148.

25 Postanowienie Sądu Najwyższego z dnia 7 stycznia 1966 r., I CR 371/65, OSNC 1966/7-8/133.

26 Postanowienie Sądu Najwyższego z dnia 8 listopada 1963 r., I PZ 48/63, OSNC 1964/6/126.

27 Do zawiadomienia prokuratora nie jest uprawniony przewodniczący wydziału na etapie dekretacji pozwu (postanowienie Sądu Najwyższego z dnia 6 kwietnia 1974 r., II PZ 9/72, LEX nr 7081).

${ }_{28}$ Powiadomienie prokuratora oznacza powinność przesłania informacji dotyczącej przesłanek uzasadniających zdaniem sądu zaangażowanie prokuratora, w tym opisu przedmiotu sprawy i jej stanu. 
za udziałem prokuratora w konkretnej sprawie. Oznacza to, że sąd winien powiadomić prokuratora o potrzebie wzięcia przez niego udziału w sprawie, gdy przemawiają za tym ochrona praworządności, praw obywateli lub interesu społecznego. Ocena, czy wystąpiła potrzeba udziału prokuratora w konkretnej sprawie należy wyłącznie do sądu, który dokonuje jej na podstawie okoliczności faktycznych sprawy, oraz kierując się oceną prawną, a zwłaszcza oceną istoty i stopnia komplikacji problemów prawnych. Słusznie uznaje się, że samo nieskorzystanie przez sąd z możliwości powiadomienia prokuratora nie stanowi pozbawienia strony możliwości obrony jej praw (nie stanowi podstawy nieważności postępowania), zaś ewentualna obraza art. 59 K.p.c. co do zasady jest naruszeniem przepisów prawa procesowego, a zatem skuteczność zarzutu tak postawionego wymaga wykazania wpływu uchybienia na treść zapadłego rozstrzygnięcia ${ }^{29}$.

Odmienną ocenę, wedle stanowiska Sądu Najwyższego, uzasadniają jedynie te szczególne przypadki, w których sąd dostrzeże, że strona postępowania, nie mająca pełnomocnika, zdradza objawy zaburzeń psychicznych powodujących u niej niezdolność do świadomego i swobodnego działania w postępowaniu ${ }^{30}$. $\mathrm{Na}$ równi z dolegliwościami natury psychicznej, w mojej ocenie, należy kwalifikować również takie niedomogi fizyczne, które uniemożliwiają działanie (np. paraliż czterokończynowy, śpiączkę). Wówczas sąd zobowiązany jest do powiadomienia prokuratora o toczącym się postępowaniu, celem umożliwienia mu przestąpienia do sprawy lub/i złożenia wniosku o ubezwłasnowolnienie.

Powyższe konstatacje prowadzą w sposób oczywisty do potrzeby udzielenia odpowiedzi na kluczowe pytanie, a mianowicie czy prokurator - zawiadomiony w trybie art. 59 K.p.c. przez sąd o potrzebie jego udziału w konkretnym postępowaniu cywilnym - władny jest uznać, że potrzeba taka nie zachodzi.

29 Postanowienie Sądu Najwyższego z dnia 13 czerwca 1997 r., I CKN 182/97, LEX nr 50612; postanowienie Sądu Najwyższego z dnia 14 stycznia 2008 r., II PK 259/07, LEX nr 864115; wyrok Sądu Apelacyjnego w Katowicach z dnia 7 marca 2014 r., I ACa 1175/13, LEX nr 1466784. Tak też P. Pogonowski, w: Kodeks postępowania cywilnego. Komentarz. Tom I. Artykuły 1-366, red. H. Dolecki, T. Wiśniewski, wyd. 2, Warszawa 2013, s. 235; M. Sychowicz, op.cit., s. 270; P. Telenga, op.cit., s. 108; A. Zieliński, w: Kodeks postępowania cywilnego. Komentarz, red. A. Zieliński, wyd. 9, Warszawa 2017, s. 131.

30 Uchwała Sądu Najwyższego z dnia 12 grudnia 1960 r., I CO 25/60, OSNCK 1961/2/32; wyrok Sądu Najwyższego z dnia 6 lutego 1969 r., III CRN 403/68, LEX nr 6451; wyrok Sądu Najwyższego z dnia 16 lipca 1971 r., III CRN 187/71, LEX nr 6961; postanowienie Sądu Najwyższego z dnia 8 października 1998 r., II CKN 903/97, LEX nr 1216978; wyrok Sądu Najwyższego z dnia 6 kwietnia 2005 r., III CK 319/04, LEX nr 175997. Tak też W. Masewicz, Prokurator ..., s. 121; P. Pogonowski, w: Kodeks ..., s. 235; E. Stefańska, w: Kodeks postępowania cywilnego. Komentarz. Tom I. Art. 1-505 ${ }^{38}$, red. M. Manowska, wyd. 3, Warszawa 2015, s. 178; M. Sychowicz, op.cit., s. 269; M. Jędrzejewska (aktualizacja P. Grzegorczyk), op.cit., s. 379; P. Telenga, op.cit., s. 109; A. Zieliński, op.cit., s. 131. 
W literaturze ${ }^{31}$ i orzecznictwie ${ }^{32}$ narosłym na gruncie Kodeksu postępowania cywilnego, który obowiązuje już ponad pięćdziesiąt lat, przeważa stanowisko, że zawiadomienie prokuratora o potrzebie jego udziału w postępowaniu nie jest dla niego wiążące i samodzielnie ocenia on, czy zachodzą przewidziane w art. 7 K.p.c. przesłanki do wzięcia udziału w sprawie, co oznacza w praktyce, że pomimo wskazania przez sąd na potrzebę udziału prokuratora w konkretnym postępowaniu, może on odmówić wstąpienia do tego postępowania. Co więcej, z przepisu tego nie sposób wywieść, że prokurator ma obowiązek wzięcia udziału w postępowaniu cywilnym, ani tym bardziej by miał on obowiązek wydania decyzji w tym przedmiocie, w szczególności decyzji podlegającej kontroli przez sąd administracyjny ${ }^{33}$ lub sąd cywilny.

Niezbędne jest jednak przytoczenie odmiennego, jak dotychczas odosobnionego, poglądu S. Grossa ${ }^{34}$, zdaniem którego przyjęcie, że zawiadomieniem dokonanym na podstawie art. 59 K.p.c. prokurator nie jest związany, pozostawałoby w sprzeczności z celami, którym służy udział prokuratora w postępowaniu cywilnym, jak i z realizacją przez sądy naczelnych zasad tego postępowania. S. Gross podniósł przy tym, że ignorowanie postanowień sądu wydawanych $\mathrm{w}$ trybie art. 59 K.p.c. nie tylko utrudniałoby postępowanie $\mathrm{w}$ tych sprawach, w których za udziałem prokuratora przemawiałyby stwierdzone przez sąd poważne racje społeczne, lecz nadto narażałoby na szwank autorytet zarówno sądu, jak i prokuratury. W konsekwencji zaproponował on taką wykładnię art. 7 K.p.c. i art. 59 K.p.c., wedle której decyzja prokuratora o zainicjowaniu postępowania lub wzięciu $\mathrm{w}$ nim udziału $\mathrm{z}$ własnej inicjatywy nie podlega ocenie sądu, podobnie jak postanowienie sądu stwierdzające potrzebę udziału

${ }^{31}$ K. Stefko, op.cit., s. 85; B. Dobrzański, Glosa [do orzeczenia Sądu Najwyższego z dnia 19 października 1965 r., I CR 286/65], Orzecznictwo Sądów Polskich 1966, z. 4, s. 189; Z. Resich, w: Kodeks ..., s. 144; W. Masewicz, Prokurator ..., s. 122-123; M. Piórkowska, Kilka refleksji w związku z udziałem prokuratora w postępowaniu cywilnym, Przegląd Ustawodawstwa Gospodarczego 1994, nr 5, s. 25; P. Wiśniewski, Udział prokuratora w postępowaniu cywilnym. Część I, Prokuratura i Prawo 1997, nr 10, s. 72-73; Z. Zawadzka, Formy ..., s. 93; P. Wiśniewski, Udział prokuratora w postępowaniu cywilnym, Toruń 2014, s. 60-62; E. Stefańska, op.cit., s. 179; M. Sychowicz, op.cit., s. 94, 270; M. Jędrzejewska (aktualizacja P. Grzegorczyk), op.cit., s. 190, 379; M. Sorysz, w: Kodeks postępowania cywilnego. Komentarz. Tom I. Art. 1-729, red. A. Góra-Błaszczykowska, wyd. 2, Warszawa 2016, s. 265; E. Rudkowska-Ząbczyk, Komentarz do art. 59, w: Kodeks postępowania cywilnego. Komentarz, red. E. Marszałkowska-Krześ, wyd. 8, Warszawa 2017 (Legalis); A. Zieliński, op.cit., s. 131.

${ }^{32}$ Zob. np. uchwała Sądu Najwyższego z dnia 24 czerwca 1966 r., III CZP 42/66, OSNC 1966/12/210; wyrok Sądu Najwyższego z dnia 10 lutego 1972 r., II CR 663/71, OSNC 1972/7-8/148; wyrok Sądu Apelacyjnego w Lublinie z dnia 10 grudnia 2013 r., I ACa 587/13, LEX nr 1416187.

${ }^{33}$ Postanowienie Naczelnego Sądu Administracyjnego w Warszawie z dnia 29 kwietnia 2011 r., I OSK 682/11, LEX nr 1081045.

${ }^{34}$ Odmiennie jednak por. S. Gross, Glosa [do wyroku Sądu Najwyższego z dnia 10 lutego 1972 r., II CR 663/71], Orzecznictwo Sądów Polskich i Komisji Arbitrażowych 1972, z. 12, s. 543. Zob. też M. Stypułkowska, Zakres uprawnień prokuratora w postępowaniu cywilnym, Nowe Prawo 1957, nr 12, s. 67-69. 
prokuratora w sprawie nie podlega ocenie prokuratora, a zatem zastosowanie się do niego nie może podlegać swobodnemu uznaniu prokuratora.

Równocześnie w orzecznictwie i literaturze uznano za niemożliwe, by prokurator nie podjął aktywności, pomimo prawidłowego powiadomienia go przez sąd o potrzebie wzięcia udziału w postępowaniu ${ }^{35}$. Dość wskazać, że praktyka odnotowuje jednak takie przypadki.

Przed przystąpieniem do udzielenia odpowiedzi na zarysowane powyżej pytanie warto zwrócić uwagę, że $\$ 353$ rozporządzenia Ministra Sprawiedliwości z dnia 7 kwietnia 2016 r. - Regulamin wewnętrznego urzędowania powszechnych jednostek organizacyjnych prokuratury wprost stanowi: Czynności prokuratora przewidziane w k.p.c. oraz w innych ustawach nie moga naruszać zasady swobody kształtowania stosunku cywilnoprawnego, chyba że treść lub cel tego stosunku sprzeciwia się jego naturze, ustawie lub zasadom współżycia społecznego. Prokurator samodzielnie ocenia przesłanki określone w art. 7 K.p.c., uzasadniajace $\dot{z} a$ danie wszczęcia postępowania cywilnego lub zgłoszenie w nim udziału. Udział prokuratora $w$ postępowaniu przed sądem, w którym strony maja zapewniona pomoc prawna, moga uzasadniać wyjątkowe okoliczności sprawy. Równocześnie od wielu lat kolejne regulaminy urzędowania powszechnych jednostek prokuratury - z dnia 11 kwietnia 1992 r. (\$ 292 ust. 2) $)^{36}$, z dnia 27 sierpnia 2007 r. (\$ 277 ust. 2) $)^{37}$, z dnia 24 marca 2010 r. (\$ 374 ust. 2) $)^{38}$, z dnia 11 września 2014 r. ${ }^{39} \mathrm{w}$ brzmieniu nadanym zmianą wprowadzoną przed jego wejściem $\mathrm{w}$ życie ${ }^{40}$ (\$ 193a ust. 2) oraz z dnia 7 kwietnia 2016 r. (\$360 ust. 2) - precyzyjnie wskazują: Prokurator zgłasza udział w sprawie, o której sad zawiadomił go, na podstawie art. 59 K.p.c.; niezgłoszenie udziału $w$ takiej sprawie może nastapić tylko w wyjątkowych przypadkach.

Mimo zatem słuszności zarzutów sformułowanych przez S. Grossa należy podzielić stanowisko, że zawiadomienie prokuratora o potrzebie jego udziału w postępowaniu cywilnym nie jest wiążące. Prokurator władny jest nie zgłosić swojego udziału. Na słuszność takiego stanowiska wskazuje już podstawowa

${ }^{35}$ Uchwała Sądu Najwyższego z dnia 12 grudnia 1960 r., I CO 25/60, OSNCK 1961/2/32; P. Wiśniewski, Udziat prokuratora w postępowaniu cywilnym, Toruń 2014, s. 177.

${ }^{36}$ Rozporządzenie Ministra Sprawiedliwości z dnia 11 kwietnia 1992 r. - Regulamin wewnętrznego urzędowania powszechnych jednostek organizacyjnych prokuratury (Dz.U. Nr 38, poz. 163).

${ }^{37}$ Rozporządzenie Ministra Sprawiedliwości z dnia 27 sierpnia 2007 r. - Regulamin wewnętrznego urzędowania powszechnych jednostek organizacyjnych prokuratury (Dz.U. Nr 169, poz. 1189 ze zm.).

${ }^{38}$ Rozporządzenie Ministra Sprawiedliwości z dnia 24 marca 2010 r. - Regulamin wewnętrznego urzędowania powszechnych jednostek organizacyjnych prokuratury (t.j. Dz.U. z 2014 r., poz. 144).

${ }^{39}$ Rozporządzenie Ministra Sprawiedliwości z dnia 11 września 2014 r. - Regulamin wewnętrznego urzędowania powszechnych jednostek organizacyjnych prokuratury (Dz.U. poz. 1218).

${ }_{40}$ Rozporządzenie Ministra Sprawiedliwości z dnia 18 grudnia 2014 r. zmieniające rozporządzenie - Regulamin wewnętrznego urzędowania powszechnych jednostek organizacyjnych prokuratury (Dz.U. poz. 1962). 
metoda wykładni - językowa. Verba legis sąd zawiadamia prokuratora, podobnie jak zawiadamia osobę, na rzecz której prokurator wytoczył powództwo (art. $56 \$ 1$ K.p.c.), zawiadamia osobę, która powinna występować w sprawie w charakterze powoda (art. $196 \$ 1$ K.p.c.), zawiadamia o toczącym się procesie o ustalenie macierzyństwa mężczyznę, którego dotyczy domniemanie pochodzenia dziecka od męża matki (art. $456^{1}$ K.p.c.) itd. Jest to w sposób oczywisty odmiennego rodzaju notyfikacja niż wezwanie do wzięcia udziału w sprawie, np. w charakterze pozwanego (art. 198 K.p.c.). Warto jednak postawić kolejne pytanie, czy regulacja ta - o zawiadomieniu, a nie wezwaniu prokuratora do udziału w postępowaniu cywilnym - powinna zostać zmieniona, a jeśli tak w jakim kierunku powinna zmierzać nowelizacja.

\section{O poważnych przesłankach uzasadniających udziału prokuratora w postępowaniu cywilnym}

W literaturze już wielokrotnie oceniano niezwykle krytycznie szeroki zakres kompetencji prokuratora w postępowaniu cywilnym, podnosząc, że elementem prawa do sądu jest nie tylko umożliwienie podmiotowi przedstawienia sprawy przez sądem, ale także zakaz naruszania jego sfery prawnej przez podmioty trzecie poprzez np. wytoczenie powództwa czy zaskarżenie orzeczenia ${ }^{41}$. O ile stanowisko to można, moim zdaniem, co do zasady podzielić w odniesieniu do

${ }^{41}$ Zob. zwłaszcza J.J. Litauer, O udziale prokuratora w procesie cywilnym. Przyczynek do rewizyi Ustaw Sąowych, Gazeta Sądowa 1896, nr 43, s. 673-677, nr 44, s. 693-698; M. Lisiewski, Podstawowe problemy struktury nowego postępowania cywilnego, Nowe Prawo 1957, nr 3, s. 12-13; W. Masewicz, Czy potrzebny jest udział prokuratora w procesie cywilnym, Nowe Prawo 1957, nr 6, s. 85-89; K. Korzan, Zagadnienia dostosowania polskiego systemu postępowania cywilnego do standardów europejskich, Radca Prawny 1996, nr 5, s. 14-15; K. Korzan, Cel i przyczyny wptywu ustawodawstw obcych na kształtowanie się systemu postępowania cywilnego w Polsce a zagadnienie odrębności narodowych, w: Jednolitość prawa sądowego a jego odrębności krajowe, red. M. Sawczuk, Lublin 1997, s. 246; P. Pogonowski, Realizacja ..., s. 74-75; J. Gudowski, O kilku naczelnych zasadach procesu cywilnego - wczoraj, dziś, jutro, w: Prawo prywatne czasu przemian. Księga pamiątkowa dedykowana Profesorowi Stanisławowi Sołtysińskiemu, red. M. Kępiński, Poznań 2005, s. 1031; A.G. Harla, Uprawnienia prokuratora do wszczęcia postępowania sądowego w sprawie cywilnej (art .7 k.p.c.) - uwagi de lege lata $i$ de lege ferenda, Palestra 2006, nr 3-4, s. 35-37; K. Weitz, Czy nowa kodyfikacja postępowania cywilnego? Państwo i Prawo 2007, z. 3, s. 26; T. Ereciński, O uwarunkowaniach, potrzebie oraz zakresie nowego kodeksu postępowania cywilnego, Polski Proces Cywilny 2010, nr 1, s. 18; K. Markiewicz, Prokurator w postępowaniu cywilnym w ujęciu historycznym, w: O prawie i jego dziejach księgi dwie. Studia ofiarowane Profesorowi Adamowi Lityńskiemu w czterdziestopięciolecie pracy naukowej i siedemdziesięciolecie urodzin, red. M. Mikołajczyk, t. 2, Białystok-Katowice 2010, s. 71-73; A. Jaworski, Udział ..., s. 87; P. Pogonowski, w: Kodeks ..., s. 76-78; K. Gajda-Roszczynialska, w: Kodeks ..., s.77; A. Kościółek, A.M. Arkuszewska, Udział prokuratora w postępowaniu cywilnym, uwagi de lege lata i de lege ferenda, w: Postępowanie rozpoznawcze w przyszłym Kodeksie postępowania cywilnego, red. K. Markiewicz, A. Torbus, Warszawa 2014, s. 541-547; K. Gajda-Roszczynialska, Udział podmiotów innych niż materialnie 
udziału prokuratora $\mathrm{w}$ charakterze strony, o tyle z dużą ostrożnością przyjrzeć się należy ewentualnym dążeniom do wykluczenia udziału prokuratora jako uczestnika postępowania niezwiązanego z żadną ze stron, gdy za jego udziałem przemawia interes publiczny.

Warto zatem zwrócić ponownie uwagę na regulację art. 59 K.p.c., ale tym razem dostrzegając $\mathrm{w}$ niej nie tyle nieuzasadnioną ingerencję prokuratora w sferę praw prywatnych, ale gwarancję efektywnej ochrony sądowej. Nawet pobieżna analiza praktyki sądowej może dowodzić, że ilość spraw cywilnych, w których sąd powiadamia prokuratora o tym, że uznaje jego udział w sprawie za potrzebny jest znikoma. Pozwala to na postawienie hipotetycznego wyjaśnienia tego fenomenu: albo sądy cywilne nie doceniają znaczenia udziału prokuratora $\mathrm{w}$ postępowaniu, albo też powiadamiają prokuratora o potrzebie wzięcia $\mathrm{w}$ nim udziału jedynie w tych wyjątkowych okolicznościach, gdy inne środki prawne nie są wystarczające dla zapewnienia należytego przebiegu postępowania sądowego. Zdecydowanie bliższe jest mi to drugie wyjaśnienie, zaś o jego implikacjach będzie mowa w dalszej części artykułu.

W tym miejscu trzeba przypomnieć, że, wstępując do postępowania, prokurator nie jest obowiązany wskazać, do której strony przystępuje ${ }^{42}$. Prokurator nie jest związany z żadną ze stron. Stosownie do własnej oceny może on składać oświadczenia i zgłaszać wnioski, jakie uzna za celowe, oraz przytaczać fakty i dowody na ich potwierdzenie, wypowiadać się co do wyników postępowania dowodowego i stanowisk procesowych oraz samego przebiegu postępowania. Od chwili, kiedy prokurator zgłosił udział w postępowaniu, należy mu doręczać pisma procesowe, zawiadomienia o terminach i posiedzeniach oraz orzeczenia sądowe $^{43}$. Podczas rozprawy na żądanie prokuratora sąd udziela mu głosu w każdym stanie rozprawy (art. $210 \$ 1$ K.p.c.). Prokurator może także zaskarżyć każde

uprawnione jako stron $w$ procesie cywilnym a kryterium interesu prawnego - zagadnienia wybrane, Polski Proces Cywilny 2015, nr 3, s. 369-370.

Ostrożniej w tym zakresie wypowiadają się natomiast A. Góra-Błaszczykowska, Wszczęcie postępowania cywilnego przez prokuratora w świetle zasady równości stron (kilka uwag na tle aktualnego stanu prawnego), Opolskie Studia Administracyjno-Prawne 2008, t. 5, s. 55-66; A. Jaworski, Uprawnienia prokuratora w postępowaniu cywilnym w przyszłym Kodeksie postępowania cywilnego - propozycja podstawowych założeń, w: Postępowanie rozpoznawcze w przyszłym Kodeksie postępowania cywilnego, red. K. Markiewicz, A. Torbus, Warszawa 2014, s. 497-527; K. Kijowski, W. Papis, Rola prokuratora $w$ postępowaniu cywilnym w świetle zmian ustrojowych prokuratury oraz transformacji ustrojowej Polski w latach 1989-2015, Kwartalnik Krajowej Szkoły Sądownictwa i Prokuratury 2015, nr 3, s. 28-38.

${ }^{42}$ M. Sychowicz, op.cit., s. 272; odmiennie Z. Resich, w: Kodeks ..., s. 147.

${ }^{43}$ Niezawiadomienie prokuratora o terminach posiedzeń sądu - mimo zgłoszenia przez prokuratora udziału w sprawie - jest uchybieniem procesowym, które może mieć wpływ na wynik sprawy. Uchybienie to nie pozbawia jednak strony możności obrony swych praw, toteż nie wyczerpuje znamion nieważności postępowania (orzeczenie Sądu Najwyższego z dnia 1 marca 1957 r., II CR 939/55, OSNCK 1959/3/67; wyrok Sądu Najwyższego z dnia 30 stycznia 1967 r., II PR 284/66, OSNC 1967/9/159). 
orzeczenie sądowe, od którego służy środek odwoławczy. Terminy do zaskarżenia orzeczeń sądowych, ustanowione dla stron, wiążą również prokuratora.

Pozycja prokuratora, który wstąpił do toczącego się postępowania cywilnego, jest zatem samodzielna, choć doktrynalnie mówi się czasem o interpretowaniu jego stanowiska z zastosowaniem dalekiej analogii do interwenienta ubocznego ${ }^{44}$. Właśnie ta samodzielność stanowiska prokuratora, nakierowana na ochronę praworządności, praw obywateli i interesu społecznego, może stanowić gwarancję efektywnej ochrony sądowej. By nie stawiać gołosłownych tez, celowe wydaje się podanie przykładu sytuacji, w której taką kwalifikację udziału prokuratora w postępowaniu można zbudować. Takiego przykładu dostarcza orzecznictwo Sądu Najwyższego, który wywiódł, iż prokurator powiadomiony o postępowaniu, którego stroną jest osoba niezdolna do czynności procesowych z powodu przeszkód psychicznych lub fizycznych, ma być w takim przypadku gwarantem zabezpieczenia interesów takiej osoby, w pierwszej kolejności jako podmiot uprawniony do wystąpienia $\mathrm{z}$ wnioskiem o jej ubezwłasnowolnienie, $\mathrm{w}$ drugiej kolejności - jako uczestnik postępowania w trybie art. 7 K.p.c. ${ }^{45}$ Co więcej, w orzecznictwie Sądu Najwyższego wyrażono nawet pogląd, że rozpoznanie bez zawiadomienia o sprawie prokuratora, sprawy strony chorej psychicznie i na skutek choroby niezdolnej do świadomego podejmowania decyzji, nie mającej ustanowionego pełnomocnika procesowego, pozbawia stronę możności obrony swoich praw, co powoduje nieważność postępowania (art. 379 pkt 5 K.p.c.) ${ }^{46}$. To ostatnie stanowisko zaaprobowali m.in. P. Grzegorczyk ${ }^{47}$, J. Gudowski ${ }^{48}$, R. Flejszar ${ }^{49}, \mathrm{P}$. Wiśniewski ${ }^{50}$ i A. Jaworski ${ }^{51}$.

Pomimo tego, że ilość spraw, w których występują nieubezwłasnowolnione osoby ciepiące na zaburzenia natury psychicznej lub fizycznej, którym niepełnosprawność faktycznie uniemożliwia podejmowanie czynności procesowych (a zatem także obronę praw w procesie), jest rzeczywiście niewielka (znikoma) niedopuszczalne byłoby marginalizowanie lub wręcz pomijanie trudności w nich występujących, ponieważ również takie osoby mają prawo do efektyw-

${ }^{44}$ W. Masewicz, Prokurator ..., s. 51-56; M. Sychowicz, op.cit., s. 93.

45 Pogląd ten wyrażono również w orzeczeniu Sądu Najwyższego z dnia 4 marca 1958 r., III CZ 9/58, LEX nr 1632081; wyroku Sądu Najwyższego z dnia 16 lipca 1971 r., III CRN 187/71, LEX nr 6961; postanowieniu Sądu Najwyższego z dnia 8 października 1998 r., II CKN 903/97, LEX nr 1216978.

${ }^{46}$ Wyrok Sądu Najwyższego z dnia 6 kwietnia 2005 r., III CK 319/04, LEX nr 175997.

${ }_{47}$ P. Grzegorczyk, w: Kodeks postępowania cywilnego. Komentarz. Tom I. Postępowanie rozpoznawcze, red. T. Ereciński, wyd. 5, Warszawa 2016, s. 443.

${ }^{48}$ J. Gudowski, w: Kodeks postępowania cywilnego. Komentarz. Tom I. Postępowanie rozpoznawcze, wyd. 5, red. T. Ereciński, Warszawa 2016, s. 519-520.

49 R. Flejszar, w: Kodeks postępowania cywilnego. Tom I. Komentarz. Art. 1-729, red. A. Góra-Błaszczykowska, wyd. 2, Warszawa 2015, s. 294.

50 P. Wiśniewski, Udział prokuratora w postępowaniu cywilnym, Toruń 2014, s. 132-134.

51 A. Jaworski, Uprawnienia ..., s. 519-520. 
nej ochrony sądowej. Sprzeczne z elementarnym poczuciem sprawiedliwości byłoby zaakceptowanie sytuacji, w której strona formalnie posiadająca zdolność procesową ${ }^{52}$, lecz faktycznie z powodu przeszkód natury prawnej lub faktycznej, nie mogąca z niej korzystać i nie mająca pełnomocnika procesowego, jest pozbawiona możliwości obrony swoich praw. Dzieje się tak np. w przypadku braku faktycznej możliwości podejmowania przez stronę czynności, których wymaga stan sprawy, jak też w przypadku, w którym procesowe oświadczenia strony są kompletnie niezrozumiałe lub oczywiście sprzeczne z wolą tej osoby. Sprzeczne $z$ zasadą rzetelnego procesu byłoby uznanie, że sąd i inne organy państwowe nie są zobowiązane do podjęcia czynności prowadzących do zapewnienie faktycznej realizacji zasady równouprawnienia stron, w tym udziału osoby, której postępowanie dotyczy, i jej wysłuchania (audiatur et altera pars), jeżeli uczestnik postępowania (powód, pozwany, uczestnik postępowania nieprocesowego itd.) z powodu przeszkód natury psychicznej lub fizycznej w praktyce nie posiada zdolności postulacyjnej.

52 Po pewnych wahaniach w orzecznictwie (uchwała Sądu Najwyższego z dnia 12 grudnia 1960 r., I CO 25/60, OSNCK 1961/2/32; wyrok Sądu Najwyższego z dnia 4 maja 1965 r., I CR 81/65, LEX nr 5795; postanowienie Sądu Najwyższego z dnia 30 marca 1966 r., I CZ 18/66, LEX nr 5959; uchwała Sądu Najwyższego z dnia 29 września 1969 r., III CZP 74/69, OSNC 1970/6/98; postanowienie Sądu Najwyższego z dnia 26 sierpnia 1970 r., I CZ 84/70, OSNC 1971/5/90; wyrok Sądu Najwyższego z dnia 16 lipca 1971 r., III CRN 187/71, LEX nr 6961; wyrok Sądu Najwyższego z dnia 19 maja 1976 r., IV PRN 8/76, LEX nr 7828; postanowienie Sądu Najwyższego z dnia 8 października 1998 r., II CKN 903/97, LEX nr 1216978; wyrok Sądu Najwyższego z dnia 16 września 1999 r., II CKN 485/98, LEX nr 1216180; wyrok Sądu Najwyższego z dnia 23 września 1999 r., II UKN 131/99, OSNP 2001/3/77; postanowienie Sądu Najwyższego z dnia 17 lutego 2004 r., III CK 38/04, LEX nr 172804; wyrok Sądu Najwyższego z dnia 6 kwietnia 2005 r., III CK 319/04, LEX nr 175997; wyrok Sądu Najwyższego z dnia 26 września 2012 r., II CSK 36/12, LEX nr 1226830; wyrok Sądu Apelacyjnego w Warszawie z dnia 18 stycznia 2013 r., I ACa 490/12, LEX nr 1293052; odmienne stanowisko zajął Sąd Najwyższy we wcześniejszych orzeczeniach: w postanowieniu z dnia 7 października 1955 r., IV CZ 185/55, LEX nr 1634353; orzeczeniu z dnia 17 października 1957 r., III CR 450/57, LEX nr 1632080; orzeczenie z dnia 4 marca 1958 r., III CZ 9/58, LEX nr 1632081; wyroku z dnia 8 kwietnia 1970 r., II PR 223/69, LEX nr 6713) i doktrynie (np. M. Sawczuk, Zdolność procesowa a stan psychiczny strony, Nowe Prawo 1959, nr 10, s. 1208-1217; M. Piekarski, Wpływ zakłócenia czynności psychicznych strony na tok procesu, Państwo i Prawo 1961, z. 7, s. 91-97; M. Sawczuk, Zdolność procesowa w postępowaniu cywilnym, Warszawa 1963, s. 65-74; M. Piekarski, Pozbawienie strony możności obrony swych praw w postępowaniu cywilnym, Warszawa 1964, s. 143-151; S. Włodyka, Zdolność sq̨dowa i procesowa w nowym ustawodawstwie cywilnym, Przegląd Ustawodawstwa Gospodarczego 1966, nr 5, s. 149; J. Bodio, Zdolność sq̨dowa a zdolność procesowa w postępowaniu cywilnym, w: Prawo wobec wyzwań współczesności, red. P. Ruczkowski, Kielce 2011, s. 53; P. Grzegorczyk, w: Kodeks .., s. 442; P. Osowy, Osoba z zaburzeniami psychicznymi jako strona procesu cywilnego - zagadnienia wybrane, w: Problematyka osób z zaburzeniami psychicznymi. Aspekty medyczne i prawne, red. K. Flaga-Gieruszyńska, B. Karakiewicz, A. Klich, Sopot 2017, s. 342-343) przyjęty został pogląd, że zdolność procesowa przysługuje w postępowaniu cywilnym także osobom pełnoletnim, które są dotknięte zaburzeniami psychicznymi, jeżeli nie orzeczono wobec nich ubezwłasnowolnienia. 
Skoro zaś problem braku faktycznej możliwości korzystania ze zdolności procesowej ${ }^{53}$ nie jest rozpatrywany na płaszczyźnie jej braku lub ograniczenia zdolności procesowej, lecz na płaszczyźnie zapewnienia możliwości należytej obrony jej praw, udział rzecznika interesu publicznego, którym jest prokurator, nabiera właściwego znaczenia, zwłaszcza w kontekście zapewnienia możliwości obrony praw tegoż uczestnika postępowania. Nie sposób nie wspomnieć, że czynności prokuratora mogą być podejmowane zarówno na ścieżce prowadzącej do ubezwłasnowolnienia takiej osoby, jak też na drodze doprowadzenia do ustanowienia dla niej pełnomocnika procesowego lub podejmowania czynności procesowych w postępowaniu z jej udziałem celem zabezpieczenia ochrony jej praw. Właśnie wówczas udział prokuratora w postępowaniu cywilnym stanowi „wentyl bezpieczeństwa” oraz stwarza większe gwarancje osiągnięcia efektywności postępowania, wyrażającej się w zapewnieniu rzeczywistej ochrony prawnej, w tym faktycznej równości stron ${ }^{54}$.

Dodatkowo należy podkreślić, że prawo do sądu ma charakter materialny, stąd efektywność ochrony sądowej powinna nie tylko zapewniać dostęp do sądu, nie tylko sprawdzenie zasadności żądań stron w rzetelnym postępowaniu sądowym, ale także gwarantować moc wiążącą orzeczenia sądowego ${ }^{55}$. W konsekwencji w udziale prokuratora jako zapobiegającym nieważności postępowania widzieć przychodzi remedium zapobiegające uchyleniu orzeczenia lub wznowieniu postępowania z powodu nieważności ${ }^{56}$. Dopuszczalność udziału prokuratora w postępowaniu cywilnym uzasadniona jest zatem zadaniami prokuratury, która ma zabezpieczyć zarówno interes publiczny, jak i interes prywatny.

\section{Podsumowanie}

Prakseologiczne spojrzenie na wewnętrzne urządzenie postępowania cywilnego skłania do refleksji nad szybkością, sprawnością i dostępnością gwarancji sądowej ochrony prawnej. O ich znaczeniu świadczy zwłaszcza to, że zasada efektywnej ochrony znalazła swój wyraz już w preambule Konwencji o ochronie praw człowieka i podstawowych wolności, stanowiącej, że jej celem jest gwarancja praw realnych i efektywnych, a nie tylko teoretycznych czy iluzorycznych. Równocześnie z szeregu spostrzeżeń wyrażonych w orzecznictwie i literaturze należy wywieść, że efektywny jest tylko taki proces, który stwarza warunki do jak najszybszego i najbardziej skutecznego rozstrzygnięcia sporu w konkretnej

\footnotetext{
53 Zob. też P. Osowy, op.cit., s. 344.

54 W. Masewicz, Prokurator ..., s. 42.

55 Tak zwłaszcza A. Łazarska, Rzetelny proces cywilny, Warszawa 2012, s. 374-381.

56 P. Wiśniewski, Udział prokuratora w postępowaniu cywilnym, Toruń 2014, s. 178.
} 
sprawie, zapewniając zarazem ochronę prawną w szerszym znaczeniu, wyrażającą się w jednolitości, stabilności orzecznictwa, ochronie osób zainteresowanych i interesu społecznego. Efektywność postępowania sądowego rozumiana jest jako cecha postępowania, która pozwala urzeczywistnić gwarancje prawa do sprawiedliwego rozpatrzenia sprawy bez nieuzasadnionej zwłoki. Poza postulatem szybkości postępowania (wydania rozstrzygnięcia w rozsądnym terminie) obejmuje ona możność rzeczywistego skorzystania z gwarancji ochrony sądowej. W świetle regulacji prawa międzynarodowego oraz konstytucyjnych nie budzi wątpliwości, że sama efektywność postępowania jest równie ważna jak trafność samego orzeczenia. Szczególnego znaczenia nabiera przy tym moc wiążąca orzeczenia jako gwarancja efektywności ochrony prawnej. Dzięki jej istnieniu strona ma zapewnioną rzeczywiście wykonalną, a nie jedynie iluzoryczną ochronę prawną, której stabilność i pewność nie mogą ulec zachwianiu przez tymczasowość czy zmienność systemu ochrony prawnej.

Niezależnie od słusznego stanowiska, że postępowanie cywilne służy ochronie interesów prywatnych, stąd też udział organów państwowych w tym postępowaniu jest niepożądany, w oparciu o przeprowadzone analizy nie sposób nie dostrzec potrzeby zachowania uprawnień prokuratora do udziału w postępowaniu cywilnym. Zwłaszcza w przypadkach, w których sąd powiadamia prokuratora o potrzebie wzięcia udziału w postępowaniu, należy uznać, że dochodzi wówczas w najpełniejszy sposób do realizacji zasady efektywnej ochrony prawnej poprzez wyrównanie pozycji procesowej stron i zapobieganie zaistnieniu wady nieważności postępowania. Stąd też w relacji art. 7 i art. 59 K.p.c. należy stwierdzić istnienie rażącej niekonsekwencji. Wprawdzie próby jej usunięcia podjęte zostały w trakcie konstruowania regulaminów wewnętrznego urzędowania jednostek organizacyjnych prokuratury, jednakże są one niewystarczające. De lege ferenda należy postulować przekształcenie zawiadomienia prokuratora o potrzebie jego udziału w postępowaniu w wezwanie do wzięcia w niej udziału. Zmiana ta usunęłaby potencjalną możliwość zignorowania postanowienia sądu przez prokuratora, co naraża na szwank autorytet zarówno sądu, jak i prokuratury.

\section{Bibliografia}

\section{Akty prawne}

Konstytucja Rzeczypospolitej Polskiej z dnia 2 kwietnia 1997 r. (Dz.U. Nr 78, poz. 483 ze zm.). Konwencja o ochronie praw człowieka i podstawowych wolności, sporządzonej w dniu 4 listopada 1950 r. w Rzymie (Dz.U. z 1993 r. Nr 61, poz. 284 ze zm.).

Ustawa z dnia 17 listopada 1964 r. - Kodeks postępowania cywilnego (tj. Dz.U. z 2016 r., poz. 1822 ze zm.). 
Ustawa z 26 października 1982 r. o wychowaniu w trzeźwości i przeciwdziałaniu alkoholizmowi (t.j. Dz.U. z 2016 r., poz. 487 ze zm.).

Ustawa z 19 sierpnia 1994 r. o ochronie zdrowia psychicznego (t.j. Dz.U. z 2016 r., poz. 546 ze zm.). Ustawa z 28 listopada 2014 r. - Prawo o aktach stanu cywilnego (t.j. Dz.U. z 2016 r., poz. 2064 ze zm.). Ustawa z dnia 28 stycznia 2016 r. - Prawo o prokuraturze (Dz.U. poz. 177 ze zm.).

Rozporządzenie Ministra Sprawiedliwości z dnia 11 kwietnia 1992 r. - Regulamin wewnętrznego urzędowania powszechnych jednostek organizacyjnych prokuratury (Dz.U. Nr 38, poz. 163).

Rozporządzenie Ministra Sprawiedliwości z dnia 27 sierpnia 2007 r. - Regulamin wewnętrznego urzędowania powszechnych jednostek organizacyjnych prokuratury (Dz.U. Nr 169, poz. 1189 ze zm.).

Rozporządzenie Ministra Sprawiedliwości z dnia 24 marca 2010 r. - Regulamin wewnętrznego urzędowania powszechnych jednostek organizacyjnych prokuratury (t.j. Dz.U. z 2014 r., poz. 144).

Rozporządzenie Ministra Sprawiedliwości z dnia 7 kwietnia 2016 r. - Regulamin wewnętrznego urzędowania powszechnych jednostek organizacyjnych prokuratury (Dz.U. poz. 508 ze zm.).

Rozporządzenie Ministra Sprawiedliwości z dnia 11 września 2014 r. - Regulamin wewnętrznego urzędowania powszechnych jednostek organizacyjnych prokuratury (Dz.U. poz. 1218).

Rozporządzenie Ministra Sprawiedliwości z dnia 18 grudnia 2014 r. zmieniające rozporządzenie - Regulamin wewnętrznego urzędowania powszechnych jednostek organizacyjnych prokuratury (Dz.U. poz. 1962).

\section{Orzeczenia}

Uchwała Trybunału Konstytucyjnego z dnia 25 stycznia 1995 r., W 14/94, OTK 1995/1/19.

Orzeczenie Sądu Najwyższego z dnia 28 stycznia 1949 r., C 1089/48, LEX nr 310177.

Postanowienie Sądu Najwyższego z dnia 7 października 1955 r., IV CZ 185/55, LEX nr 1634353.

Orzeczenie Sądu Najwyższego z dnia 1 marca 1957 r., II CR 939/55, OSNCK 1959/3/67.

Orzeczenie Sądu Najwyższego z dnia 17 października 1957 r., III CR 450/57, LEX nr 1632080.

Orzeczenie Sądu Najwyższego z dnia 4 marca 1958 r., III CZ 9/58, LEX nr 1632081.

Uchwała Sądu Najwyższego z dnia 12 grudnia 1960 r., I CO 25/60, OSNCK 1961/2/32.

Postanowienie Sądu Najwyższego z dnia 8 listopada 1963 r., I PZ 48/63, OSNC 1964/6/126.

Wyrok Sądu Najwyższego z dnia 4 maja 1965 r., I CR 81/65, LEX nr 5795.

Postanowienie Sądu Najwyższego z dnia 14 grudnia 1965 r., I CR 337/65, OSNC 1966/7-8/131.

Postanowienie Sądu Najwyższego z dnia 7 stycznia 1966 r., I CR 371/65, OSNC 1966/7-8/133.

Postanowienie Sądu Najwyższego z dnia 30 marca 1966 r., I CZ 18/66, LEX nr 5959.

Uchwała Sądu Najwyższego z dnia 24 czerwca 1966 r., III CZP 42/66, OSNC 1966/12/210.

Postanowienie Sądu Najwyższego z dnia 20 stycznia 1967 r., I CZ 149/66, OSNC 1967/9/158.

Wyrok Sądu Najwyższego z dnia 30 stycznia 1967 r., II PR 284/66, OSNC 1967/9/159.

Postanowienie Sądu Najwyższego z dnia 23 grudnia 1968 r., I PZ 67/68, LEX nr 6434.

Wyrok Sądu Najwyższego z dnia 6 lutego 1969 r., III CRN 403/68, LEX nr 6451.

Postanowienie Sądu Najwyższego z dnia 4 marca 1969 r., II CR 20/69, OSNPG 1969/6/44.

Uchwała Sądu Najwyższego z dnia 29 września 1969 r., III CZP 74/69, OSNC 1970/6/98.

Wyroku Sądu Najwyższego z dnia 8 kwietnia 1970 r., II PR 223/69, LEX nr 6713.

Postanowienie Sądu Najwyższego z dnia 26 sierpnia 1970 r., I CZ 84/70, OSNC 1971/5/90.

Wyrok Sądu Najwyższego z dnia 16 lipca 1971 r., III CRN 187/71, LEX nr 6961.

Wyrok Sądu Najwyższego z dnia 10 lutego 1972 r., II CR 663/71, OSNC 1972/7-8/148.

Postanowienie Sądu Najwyższego z dnia 6 kwietnia 1974 r., II PZ 9/72, LEX nr 708).

Wyrok Sądu Najwyższego z dnia 19 maja 1976 r., IV PRN 8/76, LEX nr 7828.

Postanowienie Sądu Najwyższego z dnia 5 grudnia 1979 r., II CZ 121/79, OSNC 1980/6/124.

Wyrok Sądu Najwyższego z dnia 9 marca 1993 r., I CR 3/93, OSNC 1993/9/165. 
Postanowienie Sądu Najwyższego z dnia 13 czerwca 1997 r., I CKN 182/97, LEX nr 50612.

Postanowienie Sądu Najwyższego z dnia 8 października 1998 r., II CKN 903/97, LEX nr 1216978.

Wyrok Sądu Najwyższego z dnia 3 lutego 1999 r., III CKN 167/98, LEX nr 483310.

Wyrok Sądu Najwyższego z dnia 16 września 1999 r., II CKN 485/98, LEX nr 1216180.

Wyrok Sądu Najwyższego z dnia 23 września 1999 r., II UKN 131/99, OSNP 2001/3/77.

Postanowienie Sądu Najwyższego z dnia 2 października 2003 r., V CZ 88/03, LEX nr 84308.

Postanowienie Sądu Najwyższego z dnia 17 lutego 2004 r., III CK 38/04, LEX nr 172804.

Wyrok Sądu Najwyższego z dnia 6 kwietnia 2005 r., III CK 319/04, LEX nr 175997.

Wyrok Sądu Najwyższego z dnia 2 sierpnia 2007 r., V CSK 109/07, OSNC 2008/9/107.

Postanowienie Sądu Najwyższego z dnia 14 stycznia 2008 r., II PK 259/07, LEX nr 864115.

Wyrok Sądu Najwyższego z dnia 26 września 2012 r., II CSK 36/12, LEX nr 1226830.

Postanowienie Sądu Najwyższego z dnia 3 grudnia 2014 r., IV CSK 365/14, LEX nr 1566730.

Postanowienie Naczelnego Sądu Administracyjnego w Warszawie z dnia 29 kwietnia 2011 r., I OSK 682/11, LEX nr 1081045.

Wyrok Sądu Apelacyjnego we Wrocławiu z dnia 1 marca 2012 r., I ACa 111/12, LEX nr 1130913.

Wyrok Sądu Apelacyjnego w Warszawie z dnia 18 stycznia 2013 r., I ACa 490/12, LEX nr 1293052.

Wyrok Sądu Apelacyjnego w Lublinie z dnia 10 grudnia 2013 r., I ACa 587/13, LEX nr 1416187.

Wyrok Sądu Apelacyjnego w Katowicach z dnia 7 marca 2014 r., I ACa 1175/13, LEX nr 1466784.

Wyrok Sądu Apelacyjnego w Krakowie z dnia 12 stycznia 2016 r., I ACa 1332/15, LEX nr 2004520.

Wyrok Sądu Apelacyjnego w Łodzi z dnia 18 lutego 2016 r., I ACa 775/15, LEX nr 2005581.

\section{Literatura}

Bień-Kacała A., Zasada praworządności i jej gwarancje w Konstytucji RP z 1997 r., w: Praworządność i jej gwarancje, red. D. Kala, Warszawa 2009.

Bladowski B., Metodyka pracy sędziego cywilisty, wyd. 3, Warszawa 2009.

Bodio J., Interes prawny a interes publiczny prokuratora wytaczającego powództwo w trybie art. 7, 57 i 189 k.p.c., Palestra 2015, nr 1-2, s. 50-59.

Bodio J., Zdolność sq̨dowa a zdolność procesowa w postępowaniu cywilnym, w: Prawo wobec wyzwań współczesności, red. P. Ruczkowski, Kielce 2011.

Broniewicz W., Powództwo prokuratora w polskim procesie cywilnym, Państwo i Prawo 1966, z. 7-8.

Broniewicz W., Prokurator w cywilnym postępowaniu kasacyjnym, Prokuratura i Prawo 1997, nr 9.

Deskiewicz Bartosz, Udział prokuratora w postępowaniu o zaprzeczenie pochodzenia dziecka poczętego w drodze sztucznej inseminacji heterologicznej, Prokuratura i Prawo 2007, nr 9.

Dobrzański B., Glosa [do orzeczenia Sądu Najwyższego z dnia 19 października 1965 r., I CR 286/65], Orzecznictwo Sądów Polskich 1966, z. 4.

Ereciński T., O uwarunkowaniach, potrzebie oraz zakresie nowego kodeksu postępowania cywilnego, Polski Proces Cywilny 2010, nr 1.

Ereciński T., Weitz K., Efektywność ochrony prawnej udzielanej przez sq̨dy w Polsce, Przegląd Sądowy 2005, nr 10.

Flaga-Gieruszyńska K., Dostęp do sq̨du a postulat humanizacji postępowania cywilnego, w: Aurea praxis. Aurea theoria. Księga pamiątkowa ku czci Profesora Tadeusza Erecińskiego, red. J. Gudowski, K. Weitz, t. 2, Warszawa 2011.

Franusz A., Dokonywanie czynności dyspozytywnych o charakterze materialnym w procesie z powództwa prokuratora na rzecz oznaczonej osoby, Prokuratura i Prawo 2016, nr 9.

Gajda-Roszczynialska K., Udział podmiotów innych niż materialnie uprawnione jako stron w procesie cywilnym a kryterium interesu prawnego -zagadnienia wybrane, Polski Proces Cywilny 2015, nr 3. 
Góra-Błaszczykowska A., Wszczęcie postępowania cywilnego przez prokuratora w świetle zasady równości stron (kilka uwag na tle aktualnego stanu prawnego), Opolskie Studia Administracyjno-Prawne 2008, t. 5.

Gross S., Glosa [do wyroku Sądu Najwyższego z dnia 10 lutego 1972 r., II CR 663/71], Orzecznictwo Sądów Polskich i Komisji Arbitrażowych 1972, z. 12.

Gudowski J., O kilku naczelnych zasadach procesu cywilnego - wczoraj, dziś, jutro, w: Prawo prywatne czasu przemian. Księga pamiątkowa dedykowana Profesorowi Stanisławowi Sołtysińskiemu, red. M. Kępiński, Poznań 2005.

Harla A.G., Uprawnienia prokuratora do wszczęcia postępowania sądowego w sprawie cywilnej (art. 7 k.p.c.) - uwagi de lege lata i de lege ferenda, Palestra $2006 \mathrm{nr}$ 3-4.

Jaworski A., Legitymacja prokuratora do złożenia wniosku o zmianę postanowienia w przedmiocie obowiązku poddania się leczeniu odwykowemu. Glosa do postanowienia z dnia 9 października 2009 r. (IV CSK 210/09), Przegląd Sądowy 2011, nr 5.

Jaworski A., Udział prokuratora w postępowaniu cywilnym przed Sądem Najwyższym, Polski Proces Cywilny 2011, nr 3.

Jaworski A., Uprawnienia prokuratora w postępowaniu cywilnym w przyszłym Kodeksie postępowania cywilnego - propozycja podstawowych założeń, w: Postępowanie rozpoznawcze w przyszłym Kodeksie postępowania cywilnego, red. K. Markiewicz, A. Torbus, Warszawa 2014.

Jodłowski J., Glosa do wyroku [Sądu Najwyższego] z 10 II 1972, II CR 663/71, Państwo i Prawo 1973, z. 4.

Kijowski K., Papis W., Rola prokuratora w postępowaniu cywilnym w świetle zmian ustrojowych prokuratury oraz transformacji ustrojowej Polski w latach 1989-2015, Kwartalnik Krajowej Szkoły Sądownictwa i Prokuratury 2015, nr 3.

Kodeks postępowania cywilnego. Komentarz, red. A. Zieliński, wyd. 9, Warszawa 2017.

Kodeks postępowania cywilnego. Komentarz, red. E. Marszałkowska-Krześ, wyd. 8, Warszawa 2017 (Legalis).

Kodeks postępowania cywilnego. Komentarz, red. Z. Resich, W. Siedlecki, t. 1, wyd. 2, Warszawa 1975.

Kodeks postępowania cywilnego. Komentarz. Tom I. Art. 1-505 $5^{38}$, red. M. Manowska, wyd. 3, Warszawa 2015.

Kodeks postępowania cywilnego. Komentarz. Tom I. Art. 1-729, red. A. Góra-Błaszczykowska, wyd. 2, Warszawa 2016.

Kodeks postępowania cywilnego. Komentarz. Tom I. Artykuły 1-366, red. H. Dolecki, T. Wiśniewski, wyd. 2, Warszawa 2013.

Kodeks postępowania cywilnego. Komentarz. Tom I. Postępowanie rozpoznawcze, red. T. Ereciński, wyd. 5, Warszawa 2016.

Kodeks postępowania cywilnego. Tom I. Komentarz do art. 1-729, red. A. Jakubecki, wyd. 7, Warszawa 2017.

Kodeks postępowania cywilnego. Tom I. Komentarz. Art. 1-366, red. A. Marciniak, K. Piasecki, wyd. 7, Warszawa 2016.

Korzan K., Cel i przyczyny wpływu ustawodawstw obcych na kształtowanie się systemu postępowania cywilnego w Polsce a zagadnienie odrębności narodowych, w: Jednolitość prawa sądowego a jego odrębności krajowe, red. M. Sawczuk, Lublin 1997.

Korzan K., Zagadnienia dostosowania polskiego systemu postępowania cywilnego do standardów europejskich, Radca Prawny 1996, nr 5.

Kosek M., Powództwo prokuratora w sprawach niemajątkowych z zakresu prawa rodzinnego, Warszawa 2016.

Kościółek A., Arkuszewska A.M., Udział prokuratora w postępowaniu cywilnym, uwagi de lege lata i de lege ferenda, w: Postępowanie rozpoznawcze w przyszłym Kodeksie postępowania cywilnego, red. K. Markiewicz, A. Torbus, Warszawa 2014.

Kozaczek M., Prokurator w postępowaniu upadłościowym, Prokuratura i Prawo 2005, nr 5.

Lisiewski M., Podstawowe problemy struktury nowego postępowania cywilnego, Nowe Prawo 1957, nr 3. 
Litauer J.J., O udziale prokuratora w procesie cywilnym. Przyczynek do rewizyi Ustaw Sądowych, Gazeta Sądowa 1896, nr 43, s. 673-677, nr 44.

Lubiński K., Udział prokuratora w postępowaniu nieprocesowym w ujęciu prawno-porównawczym, w: Proces i prawo. Rozprawy prawnicze. Księga pamiątkowa ku czci Profesora Jerzego Jodłowskiego, red. E. Łętowska, Wrocław-Warszawa 1989.

Łazarska A., Rzetelny proces cywilny, Warszawa 2012.

Markiewicz K., Prokurator w postępowaniu cywilnym w ujęciu historycznym, w: O prawie ijego dziejach księgi dwie. Studia ofiarowane Profesorowi Adamowi Lityńskiemu w czterdziestopięciolecie pracy naukowej i siedemdziesięciolecie urodzin, red. M. Mikołajczyk, t. 2, Białystok-Katowice 2010.

Masewicz W., Czy potrzebny jest udział prokuratora w procesie cywilnym, Nowe Prawo 1957, nr 6. Masewicz W., Prokurator w postępowaniu cywilnym, Warszawa 1975.

Mazowiecka L., Prokuratura w Polsce 1918-2014, Warszawa 2015.

Meszorer A., Stanowisko i czynności prokuratora w postępowaniu cywilnym, Warszawa 1957.

Osowy P., Osoba z zaburzeniami psychicznymi jako strona procesu cywilnego-zagadnienia wybrane, w: Problematyka osób z zaburzeniami psychicznymi. Aspekty medyczne i prawne, red. K. Flaga-Gieruszyńska, B. Karakiewicz, A. Klich, Sopot 2017.

Piekarski M., Pozbawienie strony możności obrony swych praw w postępowaniu cywilnym, Warszawa 1964.

Piekarski M., Wpływ zakłócenia czynności psychicznych strony na tok procesu, Państwo i Prawo 1961, z. 7.

Piórkowska M., Kilka refleksji w związku z udziałem prokuratora w postępowaniu cywilnym, Przegląd Ustawodawstwa Gospodarczego 1994, nr 5.

Pogonowski P., Realizacja prawa do sądu w postępowaniu cywilnym, Warszawa 2005.

Resich Z., Efektywność postępowania cywilnego, w: Proces i prawo. Rozprawy prawnicze. Księga pamiątkowa ku czci Profesora Jerzego Jodłowskiego, red. E. Łętowska, Wrocław-Warszawa 1989.

Resich Z., Nauka o organach ochrony prawnej, Warszawa 1973.

Sawczuk M., Zdolność procesowa a stan psychiczny strony, Nowe Prawo 1959, nr 10.

Sawczuk M., Zdolność procesowa w postępowaniu cywilnym, Warszawa 1963.

Stefko K., Udział prokuratora w postępowaniu cywilnym, Warszawa 1956.

Stypułkowska M., Zakres uprawnień prokuratora w postępowaniu cywilnym, NP 1957, nr 12.

Weitz K., Czy nowa kodyfikacja postępowania cywilnego? Państwo i Prawo 2007, z. 3.

Wengerek E., Udział prokuratora w postępowaniu cywilnym w świetle polskiej literatury prawniczej, Studia Cywilistyczne 1963, t. 3.

Wengerek E., Zakres sq̨dowej ochrony w sprawach cywilnych, Państwo i Prawo 1975, z. 3.

Wiśniewski P., Udział prokuratora w postępowaniu cywilnym, Toruń 2014.

Wiśniewski P., Udział prokuratora w postępowaniu cywilnym. Częśćl, Prokuratura i Prawo 1997, nr 10; Część ll, Prokuratura i Prawo 1997, nr 11.

Włodyka S., Udział prokuratora w postępowaniu cywilnym w świetle nowego ustawodawstwa, Nowe Prawo 1966, nr 9.

Włodyka S., Zdolność sądowa i procesowa w nowym ustawodawstwie cywilnym, Przegląd Ustawodawstwa Gospodarczego 1966, nr 5.

Zawadzka Z., Formy udziału prokuratora w postępowaniu cywilnym, Prokuratura i Prawo 2009, nr 10. Zawadzka Z., Pozycja procesowa prokuratora w postępowaniu cywilnym, Prokuratura i Prawo 2010, nr 6. Zembrzuski T., Rola Prokuratora Generalnego w cywilnym postępowaniu kasacyjnym, Prokuratura i Prawo 2006, nr 2. 


\section{Streszczenie}

Tradycyjnie rola prokuratury w systemie prawa postrzegana jest w kontekście wykonywania zadań w zakresie ścigania przestępstw i stania na straży praworządności. Warto jednak wskazać, że zgodnie z art. 7 zd. 1 Kodeksu postępowania cywilnego prokurator może żądać wszczęcia postępowania w każdej sprawie, jak również wziąć udział w każdym toczącym się już postępowaniu, jeżeli według jego oceny wymaga tego ochrona praworządności, praw obywateli lub interesu społecznego Choć szeroki zakres kompetencji prokuratora w sprawach cywilnych spotkał się z niemal powszechną krytyką w literaturze, należy z dużą ostrożnością podchodzić do dążeń do wykluczenia udziału prokuratora jako uczestnika postępowania niezwiązanego z żadną ze stron, gdy za jego udziałem przemawia interes publiczny. Zwłaszcza w przypadkach, w których sąd powiadamia prokuratora o potrzebie wzięcia udziału w postępowaniu, należy uznać, że dochodzi wówczas w najpełniejszy sposób do realizacji zasady efektywnej ochrony prawnej poprzez wyrównanie pozycji procesowej stron i zapobieganie zaistnienia wady nieważności postępowania. Z tego względu autor postuluje przekształcenie zawiadomienia prokuratora o potrzebie jego udziału w postępowaniu w wezwanie do wzięcia w niej udziału.

Słowa kluczowe: prokurator, postępowanie cywilne, efektywność postępowania sądowego, efektywność ochrony sądowej.

\section{The participation of the prosecutor in civil proceedings as a guarantee of ensuring the effectiveness of legal protection}

\section{Summary}

The role of the prosecutor in the legal system is traditionally perceived in the context of performing tasks relating to the prosecution of offences and upholding the rule of law. It is worth mentioning, however, that pursuant to Article 7 sentence 1 of the Code of Civil Procedure the prosecutor may petition to institute proceedings in any civil matter as well as participate in any pending proceedings if he considers his presence necessary to protect the rule of law, citizens' rights or social interest. While the broad competence range of the prosecutor in civil proceedings has been assessed with high criticism in the literature on numerous occasions, it is with great caution that one should view possible tendencies towards exclusion of the prosecutor as an attendant of proceedings, without affiliation to either party, when the public interest calls for their participation. Especially in the cases where the court notifies the prosecutor of the need to participate in proceedings, one ought to conclude that it is the moment when the principle of effective legal protection becomes most fully realized through equalizing the litigious position of the parties and prevention of the occurrence of a defect which might invalidate the proceedings. The author postulates transforming notification of the need to participate in proceedings served on the prosecutor into summoning for attending it.

Keywords: prosecutor, civil proceedings, effectiveness of judicial proceedings, effectiveness of judicial protection 